Available Online at https://journal.unismuh.ac.id/index.php/otoritas

Otoritas : Jurnal Ilmu Pemerintahan, 10 (2), October 2020, 176-198

\title{
Denial of the Rohingya Genocide: Problematising Daw Aung San Suu Kyi and the Rule of Law in Postcolonial Myanmar
}

\author{
Wendell Gleen P Cagape ${ }^{{ }^{*} \text { ) }}$ \\ ${ }^{1}$ Graduate School on Southeast Asian Studies, Centro Escolar University, 9 Mendiola St, San Miguel, \\ Manila, 1008, Metro Manila, Philippines.
}

Received: 26 January 2020; Revised: 30 September 2020; Accepted: 5 October 2020

\begin{abstract}
As the world condemns the genocide, Myanmar and Daw Aung San Suu Kyi's government denied it and refused to accept it and argued that it sanctioned under the rule of law. This paper problematises these questions:, What is the rule of law in Myanmar? And why do they deny it? This study is qualitative in which pages of transcripts of speeches perused to find themes, settings, and meanings attributed to problematising Daw Aung San Suu Kyi and the rule of law in post-colonial Myanmar. These speeches delivered in public from 2016-2018. In analysing her speeches, the paper uses Foucauldian Discourse Analysis. On the part of Daw Aung San Suu Kyi, it found that problematising her actions and silence over the Rohingya genocide influenced her late father's role. She continued to claim that her military father is the father of the Burmese military. She had special relations in incarceration with the army generals during her house arrest. She focused on the democratic transition which she promised in the 2015 election. This study reveals that this rule of law has purely political narratives because the generals are not accountable. This paper subsumes ongoing legal reforms in Myanmar.
\end{abstract}

Keywords: Aung San Suu Kyi; Crisis; Myanmar; Problematising; Rohingya

How to Cite: Cagape, W. G. P. (2020). Denial of the Rohingya Genocide: Problematising Daw Aung San Suu Kyi and the Rule of Law in Postcolonial Myanmar. Otoritas : Jurnal Ilmu Pemerintahan, 10(2), 176-198.

Permalink/DOI: https://doi.org/10.26618/ojip.v10i2.4642

${ }^{*}$ Corresponding Author.

E-Mail : wendellglenncagape@gmail.com

Copyright (C) 2020, Otoritas : Jurnal Ilmu Pemerintahan, ISSN: 2088-3706 (Print), ISSN: 2502-9320 (Online) 


\section{INTRODUCTION}

The United Nations Security Council, acting on its report, calls for the prosecution of Myanmar generals for crimes, among others, genocide at the International Criminal Court (Mahtani 2018 ). The Independent International FactFinding Mission on Myanmar bluntly concluded that "The gross human rights violations committed ... are shocking for their horrifying nature and ubiquity" and "undoubtedly amount to the gravest crimes under international law" says the editorial of The Washington Post (2018).

The Report of the United Nations Independent Fact-finding Mission recommends, among many others (A/HRC, 2018) are the protection of its people from genocide, crimes against humanity, and war crimes and Ensure accountability.

Independent Mission of the United Nations into Myanmar recommends that the heart of the problematise is collective silence in Myanmar on the crimes against the Rohingya.

Yanghee Lee (United Nations Special Rapporteur for Myanmar) said in her address to the United Nations Human Rights Council in Geneva, Switzerland in early March 2018 that the crimes committed between 9, October 2016 and 25, August 2017 carried the hallmarks of genocide and called for accountability. The same sentiments were shared by the then UN Human Rights Chief Zeid Ra'ad al-Hussein who informed the UN Human Rights Council that an "act of genocide" may have taken place in the Rakhine targeting the Rohingya. Following this, in July 2018, one of the international NGOs monitoring human rights abuses in Southeast Asia and Myanmar, the FortifyRights accused ranking Myanmar military officials of "planned genocide".

However, the Myanmar military denied these allegations of genocide against the Rohingya. It accused Facebook of un- dermining them after the social media giant removed pages and accounts related to them after the damning UN report of Rohingya genocide was released.

While the Myanmar military denied the Rohingya genocide, Daw Aung San Suu Kyi stayed silent. Her critics, including the UN Human Rights Chief, called for her resignation over the Rohingya crisis.

Following the UN Report on the Rohingya Genocide, Canada also referred to the Rohingya crisis as genocide and accused Myanmar of committing genocide against the Rohingya people. The US too sanctioned the Myanmar military over ethnic cleansing and genocide.

With this backdrop, the Myanmar military establishment and Daw Aung San Suu Kyi, the State Counselor of Myanmar refused to admit guilt or acknowledge genocide against the Rohingya. They opposed it and evaded accountability as pressures mounting for the United $\mathrm{Na}$ tions Security Council to discuss it in its meeting and refer the Rohingya to the International Criminal Court at The Hague.

At the United Nations, the Third Committee aired their deep distress and reported that unarmed Rohingya in Rakhine State subjected to the unlawful use of force by non-state actors. Excessive use of force by the military and security forces, including extrajudicial killings, rape and other forms of sexual violence, arbitrary detention and the unexplained disappearance of Rohingya civilians in Rakhine State, and reported large scale destruction of homes and systematic evictions in northern Rakhine State, including the use of arson and violence (Committee, 1957). These are elements of ethnic cleansing and genocide targeting the Rohingya in the northern Rakhine State.

The Problem Statement, Research Questions and Objectives

Central to the study's thesis is Daw Aung San Suu Kyi's stand on the issue of atrocities against the Rohingya since 
2017. Her silence is what drives us to ask: Why won't she act?

Specifically, the study looks at the corpus commonly used in her speeches and draw analysis on what could perhaps explain her silence.

This study aims to problematise Daw Aung San Suu Kyi's behaviours and the concept of the 'rule of law' in Myanmar, which is the widely used reason of government's actions against the atrocities on the Rohingya.

\section{LITERATURE REVIEW AND THEORETI- CAL FRAMEWORK}

Despite the atrocities against the Rohingya, Daw Aung San Suu Kyi remains non-committal, refused to comment or issue a statement against the military generals for what has happened on 25 August 2017. One member of her inner circle wrote: "She will never do what Nambiar tells her to do." Nor will she ever concede that the Rohingya Muslims are subject to ethnic cleansing, not even when tens of thousands burnt from their homes amid widespread reports of killing and sexual violence (Keane, 2018).

Discourse defined as a group of ideas or patterned way of thinking, which can be identified in textual and verbal communications and can locate in broader social structures' (Lupton, 1992). In this manner, speeches become a great source of data to study spoken words to extract meanings related to social processes and analyse it in the purview of how language works within power relations. Further, discourse analysis requires a deeply reflexive approach to recognise the rules of formation and understand power relations patterns through selfconscious analytical scrutiny (England, 1994).

FDA draws its lineage from Critical Discourse Analysis (CDA). The CDA widely used in analysing speeches of world leaders. CDA provide some approaches to research with the primary aim of uncovering the relationship between language, society, power, ideology, values and opinions(Rahimi \& Riasati, 2011). In this, discourse played a crucial role in determining the dominant narratives while also acknowledging the marginalised narratives. We better understand this when we go back to Michel Foucault's arguments in his book Archaeology of Knowledge. He quipped that "I have decided to ignore no form of discontinuity, break, threshold, or limit. I have decided to describe statements in the field of discourse and the relations of which they are capable" (Foucault, 1972). However, in his pursuits to study discourse, he also proposed exclusionary mechanisms which pertain to taboos, rituals and privileges of the speaking subject. These prohibition forms seem reasonably straightforward, and Foucault does not spend much time elaborating them, noting that where the (intersecting) grid of prohibition is tightest is in the regions of politics and sexuality(Foucault, 1970). So, in studying Daw Aung San Suu Kyi's speeches, we investigate her words under the scalpel of the four hypotheses of Michel Foucault under Archaeology of Knowledge and analyse further her exclusionary mechanism since the issue of the Rohingya genocide lands on the lap of political discourse.

Following Foucault, we must question that ready-made synthesis, those groupings that we usually accept before any examination, those links whose validity is recognised from the outset. We must oust those forms and mysterious forces by which we typically link the discourse of one man with that of another; they must drive out from the darkness in which they reign (Foucault, 1972).

And with the discourse found in her publicly delivered speeches, we take every word and sentences at face value. For in Foucault, he quipped:

"holds that statements are performances which have face value regardless 
of both the possible ambiguity of the sentences used in their formulation (such ambiguous sentences are the subject of commentaries on texts) and the causal factors involved in their utterance (such causal factors are studied hermeneutically, for example in the psychoanalysis of everyday life)(Dreyfus \& Rabinow, 1983).

Foucault's theorisation of the constitutive and disciplinary properties of discursive practices within socio-political relations of power demonstrates the postmodern concern with how language works to produce meaning and particular kinds of objects and subjects through which specific power relations are realised (Luke 1999). In this locus, we dissect Aung San Suu Kyi's speeches to find ties between her objects and her narratives' subjects to problematise somehow her position as someone who used to be the West's darling with a moniker of the "Democracy Icon" of Southeast Asia.

Finally, Foucault said:

"The quest for the primary designations of language drew out from the silent and innermost heart of words, syllables, and sounds themselves, a dormant representation that formed, as it were, their forgotten soul (which it was necessary to bring back to the light, to speak and sing once more, to attain a greater exactitude of thought, a more miraculous power of poetry); similarly, for modern thought, the inert density of the unthought is always inhabited in a certain manner by a cogito, and this thought is dormant within what not thought, must be brought to life again and stretched out in the sovereignty of the 'I think'" (Maniglier, 2013).

One crucial presupposition of adequate critical discourse analysis understands the nature of social power and dominance. Once we have such insight, we may begin to formulate ideas about how discourse contributes to reproduction(van Dijk, 1993).

\section{RESEARCH METHODS}

The methodology is one of the central thesis of this paper. We intend to problematise Kyi's actions and refusal to tackle the issue using the Foucauldian Discourse Analysis (FDA), looking at her speeches delivered at the Nay Pyi Taw and other public fora including the Keynote address on Development Effectiveness Roundtable, Speech on the National Reconciliation and Peace, Speech on Democratic Transition in Myanmar: Challenges and the Way Forward, her Adress before His Holiness, Pope Francis in Myanmar as delivered at the Myanmar International Convention Center, her message on the Union Peace Conference 21st Century Panglong, Speech on the commemorative ceremony of the 50th ASEAN anniversary, her report to the People, and her speech at the 71st United Nations General Assembly in New York.

The study limits her public speeches in analysing meaning using the FDA and taking only those spoken by Daw Aung San Suu Kyi from 2016-2018. Speeches sourced from the official website of the State Counselor of Myanmar at www.statecounsellor.gov.mm.

Foucauldian Discourse Analysis (FDA) evolved from Critical Discourse Analysis as commonly used to analyse various leaders' spoken and written speeches and their situations. It will be employed to gather meanings from words as spoken by Daw Aung San Suu Kyi in her public engagements inside Myanmar and within ASEAN and the United $\mathrm{Na}$ tions.

We intend to peruse Daw Aung San Suu Kyi's speeches for relations between discourse, power, dominance, social inequality, and positioning. In this paper, we approach these realities by focusing on discourse in the production or challenge of dominance (van Dijk, 1993). Dominance, continued van Dijk, is defined as the exercise of social power by elites, institutions or groups, resulting in social 
inequality, including political, cultural, class, ethnic, racial and gender inequality (Van dijk, 1993).

\section{RESULTS AND DISCUSSION}

The following are the speeches under review in this paper.

Sample 1 is the speech given by Daw Aung San Suu Kyi on 17 September 2017 delivered publicly during the National Reconciliation and Peace at Nay Pyi Taw, in Myanmar;

Sample 2 is the speech given by Daw Aung San Suu Kyi on 21 September 2016 delivered publicly during the 71st United Nations General Assembly in New York, USA;

Sample 3 is the speech given by Daw Aung San Suu Kyi on 28 November 2017 delivered publicly upon the Apostolic Visit of His Holiness Pope Francis to Myanmar, in the Myanmar International Convention Center;

Sample 4 is the speech given by Daw Aung San Suu Kyi on 23 August 2018 delivered publicly on the 43rd Singapore Lecture in Singapore;

Sample 5 is the speech given by Daw Aung San Suu Kyi on 26 February 2018 delivered publicly at Nay Pyi Taw, in Myanmar on the Development Effectiveness Roundtable;

Sample 6 is the speech given by Daw Aung San Suu Kyi on 27 January 2018 delivered publicly at the Union Peace Conference 21st Century Panglong;

Sample 7 is the speech given by Daw Aung San Suu Kyi on 14 August 2017 on the Golden Anniversary of the ASEAN at Nay Pyi Taw, Myanmar;

Sample 8 is the speech given by Daw Aung San Suu Kyi on 12 October 2017 as her report to the People, at Nay Pyi Taw, Myanmar.

In the table 1 , statistical data presented per speech samples generated from the MS Word processor.

The top seven most commonly found words in her speech in the National Rec- onciliation and Peace refer to mostly the "desirables" she envisions Myanmar shall achieve after the Rohingya exodus on 26 August 2017 Cox's Bazar in Bangladesh. She repeatedly speaks of 'peace' in a string of words such as in "peace and stability"; and more strings of words such as in "democratic transition, peace and stability and development". The same goes for "development" and refusing to call the Rohingya, Rohingya. She mentioned them as "Muslim/Muslims" 11 times in her speech. Similarly, she referred northern Rakhine State (nRS) as "Rakhine" to subsume the entire swath of land which also includes the Buddhist-majority southern Rakhine State. Mindful that the international community was looking in 2017 at the atrocities particularly happened in northern Rakhine State.

In this speech, she mentioned "the rule of law" only three times. She used it to commit her government "to the restoration of peace, stability and the rule of law, throughout the State". In her discourse statement, State refers to the northern Rakhine State (nRS) which she aptly referred to as the "Rakhine". It provides a false representation of the State because there were no "clearance operations" ever undertaken in the "southern Rakhine State", which were taken only in the "northern Rakhine State" where most of the Rohingya population settles.

"Clearance Operations" refers to the Myanmar Tatmadaw's response on the Rohingya population following the $25 \mathrm{Au}$ gust 2017 attacks on thirty police outposts, was mentioned only twice. To my analysis, this was intentional.

Daw Aung San Suu Kyi framed her discourse to shield the Myanmar Tatmadaw, and its country ranked military officials. She narrowly referred in her speech, "clearance operations", in the same vein as she refused to refer to the Rohingya on their ethnic group's name but rather as "Muslim or Muslims".

On sample 2, table 3 are the corpora. 
Available Online at https://journal.unismuh.ac.id/index.php/otoritas

Otoritas : Jurnal Ilmu Pemerintahan, 10 (2), October 2020, 181

Table 1. Overall Corpus of All Sample 8 Speeches of Daw Aung San Suu Kyi

Source: Processed by the Author (2019)

\begin{tabular}{|c|c|c|c|c|c|c|c|c|}
\hline $\begin{array}{l}\text { Statisti- } \\
\text { cal Items }\end{array}$ & $\underset{1}{\text { Sample }}$ & $\begin{array}{c}\text { Sample } \\
2\end{array}$ & $\begin{array}{l}\text { Sam- } \\
\text { ple } 3\end{array}$ & $\begin{array}{l}\text { Sam- } \\
\text { ple } 4\end{array}$ & $\begin{array}{l}\text { Sam- } \\
\text { ple } 5\end{array}$ & $\begin{array}{l}\text { Sam- } \\
\text { ple } 6\end{array}$ & $\begin{array}{l}\text { Sam- } \\
\text { ple } 7\end{array}$ & $\begin{array}{l}\text { Sam- } \\
\text { ple } 8\end{array}$ \\
\hline Pages & 6 & 3 & 2 & 5 & 4 & 2 & 2 & 2 \\
\hline Words & 3,654 & 1,641 & 923 & 3,489 & 1,692 & 1,413 & 962 & 1,136 \\
\hline $\begin{array}{l}\text { Charac- } \\
\text { ters with } \\
\text { no spaces }\end{array}$ & 17,219 & 8,413 & 4,417 & 18,154 & 9,017 & 6,962 & 5,197 & 5,666 \\
\hline $\begin{array}{l}\text { Charac- } \\
\text { ters with } \\
\text { spaces }\end{array}$ & 20,836 & 10,033 & 5,335 & 21,597 & 10,673 & 8,466 & 6,140 & 6,868 \\
\hline $\begin{array}{l}\text { Para- } \\
\text { graphs }\end{array}$ & 45 & 24 & 13 & 50 & 50 & 20 & 19 & 21 \\
\hline Lines & 237 & 120 & 68 & 241 & 146 & 92 & 68 & 79 \\
\hline
\end{tabular}

Table 2. Corpus from the Speech Delivered on September 17, 2017 by Daw Aung San Suu Kyi at the National Reconciliation and Peace at Nay Pyi Taw Source: statecounsellor Website (2019)

\begin{tabular}{|c|c|c|c|c|}
\hline Top Words & $\begin{array}{l}\text { Number of } \\
\text { times found in } \\
\text { the speech }\end{array}$ & Versus & Bottom Words & $\begin{array}{c}\text { Number of } \\
\text { times found in } \\
\text { the speech }\end{array}$ \\
\hline Peace & 22 & & Bangladesh & 4 \\
\hline Development & 14 & & Refugees & 4 \\
\hline Rakhine & 14 & & Democracy & 3 \\
\hline Myanmar & 11 & & Democratic & 3 \\
\hline Muslim/s & 10 & & Rule of Law & 3 \\
\hline Conflict & 9 & & Right & 3 \\
\hline \multirow[t]{5}{*}{ Stability } & 7 & & $\begin{array}{l}\text { Clearance Oper- } \\
\text { ations }\end{array}$ & 2 \\
\hline & & & Justice & 1 \\
\hline & & & Armed Groups & 1 \\
\hline & & & $\begin{array}{l}\text { Terrorist } \\
\text { Groups }\end{array}$ & 1 \\
\hline & & & Armed clashes & 1 \\
\hline
\end{tabular}


Available Online at https://journal.unismuh.ac.id/index.php/otoritas

Otoritas : Jurnal Ilmu Pemerintahan, 10 (2), October 2020, 182

Table 3. Corpus of the September 21, 2016 Speech of Daw Aung San Suu Kyi Delivered at the UN General Assembly in New York, USA.

Source: statecounsellor Website (2019)

\begin{tabular}{llll}
\hline Top Words & $\begin{array}{l}\text { Number of Versus } \\
\text { times found in } \\
\text { the speech }\end{array}$ & Bottom Words & $\begin{array}{l}\text { Number of } \\
\text { times found in } \\
\text { the speech }\end{array}$ \\
\hline Peace & 10 & National Recon- & 4 \\
Development & 9 & ciliation & 3 \\
Myanmar & 5 & Rakhine & 3 \\
& & Stability & 3 \\
& & Migration & 3 \\
& & Extremism & 3 \\
& & Corruption & 3 \\
& Right & 2 \\
& Fear & 2 \\
& Hatred & 1 \\
& Human rights & 1 \\
& & Citizenship & 1 \\
& & Rule of Law & 1 \\
& & Ignorance & 1 \\
& &
\end{tabular}

Table 4. Corpus of the November 28, 2017 speech of Daw Aung San Suu Kyi Delivered During the Apostolic Visit of His Holiness Pope Francis to Myanmar

Source: statecounsellor Website (2019)

\begin{tabular}{|c|c|c|c|}
\hline Top Words & $\begin{array}{l}\text { Number of Versus } \\
\text { times found in } \\
\text { the speech }\end{array}$ & Bottom Words & $\begin{array}{l}\text { Number of } \\
\text { times found in } \\
\text { the speech }\end{array}$ \\
\hline \multirow[t]{7}{*}{ Peace } & 7 & Independence & 2 \\
\hline & & Myanmar & 2 \\
\hline & & $\begin{array}{l}\text { National Recon- } \\
\text { ciliation }\end{array}$ & 2 \\
\hline & & $\begin{array}{l}\text { Founded on } \\
\text { Laws }\end{array}$ & 1 \\
\hline & & Rights & 1 \\
\hline & & Rakhine & 1 \\
\hline & & Development & 1 \\
\hline
\end{tabular}


Daw Aung San Su Kyi's United Nations General Assembly first address this speech after her party's National League for Democracy won an impressive win in parliamentary elections in 2015.

She repeatedly used 'peace' at 10 times, 'development' at 9 times, and Myanmar at 5, times. In her UNGA speech, it inferred that she was appealing to another international audience which listens to her 'promising democracy' discourse position over 'the rule of law', 'human rights', and "citizenship" when it pertains to the Rohingya issue.

It is noteworthy also to understand that in this speech, there were no massive atrocities against the Rohingya groups by the Tatmadaw as the unfortunate events would have to happen on 6 October 2016, roughly 18 days after she delivered this address.

On Sample 3, table 4 are the corpora.

This address was before His Holiness Pope Francis, and understandably, Daw Aung San Suu Kyi's repeated word is "peace" for seven times throughout her brief speech.

On the other hand, she also used "independence" twice and "Myanmar" twice in her speech. Pope Francis's visit happened on 28 November 2017, roughly around three months after the Rohingya exodus to Bangladesh after the Tatmadaw implemented clearance operations. She was perhaps anticipating a statement by His Holiness the Pope, echoing international criticism on Myanmar on its handling of the human disaster. She subtly reminded her audience and the Holy See's officials that Myanmar is an independent state, which will not be interfered.

"Founded on Laws" which we supposed to refer to "the rule of law" was used only once in her address, along with the reference of "Rakhine" uttered only once, "rights" and "development".

On Sample 4, table 5 are the corpora

Her speech before her audience at the Grand Hyatt Singapore is her 43rd
Singapore Lecture sponsored by the ISEAS. Her audiences are mostly businesspeople, enterprise leaders, global leaders, government officials and economists.

For this speech, she pitched "Myanmar" for twenty-two times while maintaining "transition" by sixteen times. She also used the word "peace" for thirteen times, ASEAN for nine times, "democracy" seven times.

Her direct discourse reference on the Tatmadaw and its dictatorship registered only the word "dictatorship" twice while using the word "rule of law" for three times.

On sample 5 , table 6 are the corpora.

This speech addressed to an audience of businesspeople in Myanmar.

In this speech, she used "development" twenty-two times and "Myanmar" for fifteen times. She was pitching development effectiveness in this roundtable with key industry leaders and business people.

She discussed on the issued which has unfolded in "Rakhine" by using the word for four times, batted for "peace" for three times, "international community" for three times and "national reconciliation" for two times.

On sample 6, table 7 are the corpora.

Daw Aung San Suu Kyi delivered this speech on the Union Peace Conference21st Century Panglong attended by representatives of the government, Parliament members, the Armed Forces, ethnic armed groups, political parties and civil society organisations.

Again, "peace" is repeated 13 times throughout her speech and "people" for eleven times, which refers to the majority and minority ethnic groups in Myanmar, except the Rohingya. "Union" refers to Myanmar's republic, used ten times and country, which refers again to Myanmar used five times.

It is noteworthy to observe too that national reconciliation was only used 
Available Online at https://journal.unismuh.ac.id/index.php/otoritas

Otoritas : Jurnal Ilmu Pemerintahan, 10 (2), October 2020, 184

Table 5. Corpus of the August 23, 2018 Lecture of Daw Aung San Suu Kyi at the 43rd Singapore

Source: Statecounsellor Website (2019)

\begin{tabular}{|c|c|c|c|c|}
\hline Top Words & $\begin{array}{l}\text { Number of } \\
\text { times found in } \\
\text { the speech }\end{array}$ & Versus & Bottom Words & $\begin{array}{c}\text { Number of } \\
\text { times found in } \\
\text { the speech }\end{array}$ \\
\hline Myanmar & 22 & & Bangladesh & 4 \\
\hline Transition & 16 & & Rule of Law & 3 \\
\hline Peace & 13 & & Dictatorship & 2 \\
\hline Rakhine & 12 & & Freedom & 2 \\
\hline ASEAN & 9 & & $\begin{array}{l}\text { National Recon- } \\
\text { ciliation }\end{array}$ & 2 \\
\hline Democracy & 7 & & & \\
\hline Development & 6 & & & \\
\hline $\begin{array}{l}\text { Democratic } \\
\text { Transition }\end{array}$ & 5 & & & \\
\hline
\end{tabular}

Table 6. Corpus of the February 26, 2018 Speech of Daw Aung San Suu Kyi at the Development Effectiveness Roundtable

Source: Statecounselor Website (2019)

\begin{tabular}{|c|c|c|c|c|}
\hline Top Words & $\begin{array}{c}\text { Number of times } \\
\text { found in the } \\
\text { speech }\end{array}$ & Versus & Bottom Words & $\begin{array}{c}\text { Number of } \\
\text { times found in } \\
\text { the speech }\end{array}$ \\
\hline Development & 22 & & Rakhine & 4 \\
\hline \multirow[t]{3}{*}{ Myanmar } & 15 & & Peace & 3 \\
\hline & & & $\begin{array}{l}\text { International } \\
\text { community }\end{array}$ & 3 \\
\hline & & & $\begin{array}{l}\text { National Recon- } \\
\text { ciliation }\end{array}$ & 2 \\
\hline
\end{tabular}

Table 7. Corpus of the January 27, 2018 Speech of Daw Aung San Suu Kyi at the Union Peace Conference 21st Century Panglong

\begin{tabular}{|c|c|c|c|c|}
\hline Top Words & $\begin{array}{c}\text { Number of times } \\
\text { found in the } \\
\text { speech }\end{array}$ & Versus & Bottom Words & $\begin{array}{c}\text { Number of } \\
\text { times found in } \\
\text { the speech }\end{array}$ \\
\hline Peace & 13 & & Myanmar & 3 \\
\hline People & 11 & & Conflict & 3 \\
\hline Union & 10 & & Potential & 2 \\
\hline \multirow[t]{5}{*}{ Country } & 5 & & Development & 1 \\
\hline & & & Federalism & 1 \\
\hline & & & Nation & 1 \\
\hline & & & $\begin{array}{l}\text { National recon- } \\
\text { ciliation }\end{array}$ & 1 \\
\hline & & & Democratic & 1 \\
\hline
\end{tabular}


once so with "democratic", "federalism", "nation" and "development" she, cited "conflict" three times in this speech.

On sample 7, table are the corpora.

This speech delivered on the golden commemorative ceremony marking the 50th Anniversary of ASEAN at Nay Pyi Taw.

In this speech, she appeared to her audience without much concern on the Rohingya since the latest atrocities have done unto them happened a year earlier. It delivered 11 days before the attacks at the police outposts in the northern Rakhine State and more than 11 days before the Tatmadaw's clearing operations against the Rohingya.

"ASEAN" used forty-two times, and community used nine times. She affectionately referred to the ASEAN's historical past as a community and placed her narratives of its future as a close-knit community of nations.

Subtly again, she mentioned, "noninterference", "trust", dialogue" and "cooperation" once while "rule-based" which is related to "the rule of law" argument used twice.

On sample 8, table 9 are the corpora.

Daw Aung San Suu Kyi's speech delivered as her report to the People months after the Rohingya exodus towards Bangladesh.

She used the word "people" eleven times and mentioned "Rakhine" seven times while "development" was used five times along with "Bangladesh" for five times.

She mentioned "peace" for four times, "resettlement" four times, "unity" for three times, "rehabilitation" twice and "repatriation" once and "international community" once.

It is noteworthy that in all her speeches, we didn't find "Rohingya" but Muslim/s and we didn't find northern Rakhine State but "Rakhine State" instead. We found "the rule of law" used only ten times across all eight speeches.
We shall, henceforth, analyse the discourse using the four-hypothesis test of Michel Foucault.

1st Hypothesis - Statements different in form, and dispersed in time, form a group if they refer to the same object;

Under this hypothesis, we come up with a group we infer in the future as themes. These are avoidance, excuse, resolved, acknowledgement and rejecting international pressures.

Under avoidance theme, the discourse revealed in this passage of her speech at the Union Peace Conference21st Century Panglong, we quote:

"We will not resort to exerting pressure through populist politics or coercing others through political means to achieve our goals" (Suu Kyi 2017). Though not directly attributed to the August 2017 exodus of the Rohingya due to the 'clearing operations' of the Tatmadaw against them. It refers to efforts of her government to sustain national reconciliation among ethnic groups, however, excluding the Rohingya.

Resting under the umbrella of the ASEAN, she avoided the issue of the Rohingya atrocities, including ethnic cleansing and genocide by citing:

"ASEAN provides a model for peaceful borders, and wider regional harmony. ASEAN's recipe for success is consultation and more consultation until a consensus reached and cooperation made possible" (Suu Kyi, Speech 2017 ). Here, this passage infers to the October 2016 atrocities that resulted in the Rohingya dispersal to Bangladesh after 'clearing operations' were done by the Tatmadaw.

She also said that "since 5 September, there have been no armed clashes and there have been no clearance operations" (Suu Kyi, Speeches 2017 ). The Tatmadaw is undertaking clearance operations, and a steady exodus of Rohingya towards Bangladesh even past this date will attest otherwise.

Under the excuse theme, she said, 
Available Online at https://journal.unismuh.ac.id/index.php/otoritas

Otoritas : Jurnal Ilmu Pemerintahan, 10 (2), October 2020, 186

Table 8. Corpus of the August 14, 2017 Speech of Daw Aung San Suu Kyi during the Golden Anniversary of the ASEAN

Source: Statecounsellor Website (2019)

\begin{tabular}{|c|c|c|c|c|}
\hline Top Words & $\begin{array}{l}\text { Number of times } \\
\text { found in the speech }\end{array}$ & Versus & Bottom Words & $\begin{array}{l}\text { Number of } \\
\text { times found in } \\
\text { the speech }\end{array}$ \\
\hline ASEAN & 42 & & Rule-based & 2 \\
\hline \multirow[t]{8}{*}{ Community } & 9 & & interest & 2 \\
\hline & & & Development & 2 \\
\hline & & & Diversity & 2 \\
\hline & & & Myanmar & 1 \\
\hline & & & $\begin{array}{l}\text { Non- } \\
\text { interference }\end{array}$ & 1 \\
\hline & & & Cooperation & 1 \\
\hline & & & Trust & 1 \\
\hline & & & Dialogue & 1 \\
\hline
\end{tabular}

Table 9. Corpus of the October 12, 2017 Speech of Daw Aung San Suu Kyi on Her Report to the People

Source: Statecounsellor Website (2019)

\begin{tabular}{|c|c|c|c|c|}
\hline Top Words & $\begin{array}{l}\text { Number of times } \\
\text { found in the speech }\end{array}$ & Versus & Bottom Words & $\begin{array}{l}\text { Number of } \\
\text { times found in } \\
\text { the speech }\end{array}$ \\
\hline People & 11 & & Peace & 4 \\
\hline Rakhine & 7 & & Resettlement & 4 \\
\hline Development & 5 & & Unity & 3 \\
\hline \multirow[t]{3}{*}{ Bangladesh } & 5 & & Rehabilitation & 2 \\
\hline & & & Repatriation & 1 \\
\hline & & & $\begin{array}{l}\text { International } \\
\text { community }\end{array}$ & 1 \\
\hline
\end{tabular}


and we quote:

"I think it only fits that I should remind you today that our government has not yet been in power for even eighteen months. It will be eighteen months at the end of this month. Eighteen months is a short time in which to expect us to meet and overcome all of the challenges that expected to do" (Suu Kyi, Speeches 2017).

In her speech, this passage was an apparent excuse in response to the growing international pressure that demands her to do more for the Rohingya issue and the atrocities used against them. She has laid down the premise that she can't address the Rohingya issue exactly because her government has just been in office for barely eighteen months. She can not respond to the challenge by condemning the Tatmadaw for its crimes against the Rohingya.

Under the resolved theme, we found important passages in her speeches.

Speaking before the 71st United Nations General Assembly, the Rohingya on 21 September 2016, Daw Aung San Suu Kyi said:

"Over the last few years, the world focused its attention on the situation in the Rakhine State of the country. As a responsible member of the community of nations, we do not fear international scrutiny" (Suu Kyi, Speeches 2016).

When international NGOs, vital influential people, from Nobel Peace Laureates to the UN officials, former UN Human Rights Council chief and the UN Special Rapporteur on Myanmar, Ms Yanghee Lee, has condemned Myanmar she assuaged their condemnation. She said "as part of our Government commitment to finding lasting stability and harmony, we support broad-based, inclusive socioeconomic development in Rakhine State, and indeed, throughout the nation. We have established the Union Enterprise for Humanitarian Assistance, Resettlement and Development in Rakhine State, the Rakhine Advisory Commission, Implementation Committee and the Rakhine Advisory Board." (Suu Kyi, Speeches, 2018). She said this while addressing the business and industry leaders during the Development Effectiveness Roundtable held on 26 February 2018 in Nay Pyi Taw.

In her most recent speaking engage-

Table 10. Corpora on the use of rule of law across all 8 speeches of Daw Aung San Suu Kyi Source: Processed by the Author (2019)

\begin{tabular}{lll}
\hline $\begin{array}{c}\text { Number the corpus "rule } \\
\text { of law" used }\end{array}$ & Sample & Alternative corpus used \\
\hline 3 & 1 & \\
1 & 2 & "Founded on Laws" \\
1 & 3 & \\
3 & 4 & \\
- & 5 & "rule-based" \\
- & 6 & \\
2 & 7 & \\
1 & 8 & Total corpora in all eight (8) \\
& & speeches \\
\hline Total corpus "rule of law" & 14,910 \\
\hline used & & \\
\hline 10 & & \\
\hline
\end{tabular}


ment in Singapore, she said that:

"Addressing destabilising issues in Rakhine State was a fundamental part of building our Pillar 1 . Within two months of taking government responsibilities, we established the Central Committee for Rule of Law and Development in Rakhine. Soon after, we approached Dr Kofi Annan, former Secretary-General of the United Nations, to head an Advisory Commission that would help us to find lasting solutions to the problems that were jeopardising peace and progress in a region so bountifully blessed by nature" (Suu Kyi, Speeches 2018 ).

And;

"On their recommendation, an Independent Commission of Enquiry, led by Ambassador Rosario Manalo, an eminent diplomat from ASEAN, has been established. The Commission met for the first time in Nay Pyi Taw on 15 August and will be commencing their work next week" (Suu Kyi, Speeches 2018).

These statements were in anticipation of the passage and voting of the draft UN Resolution recommending endorsement by the United Nations Security Council of Myanmar to the International Criminal Court (ICC).

Under acknowledgement theme, Daw Aung San Suu Kyi said:

"from many challenges that our government is facing, the situation in the Rakhine has most strongly captured the attention of the world" (Suu Kyi, Speeches 2017). This acknowledgement that the atrocities against the Rohingya have reached the international radar and scale was at the centre of her address to visiting Pope Francis in Nay Pyi Taw. She also acknowledged that the compassion and encouragement that His Holiness Pope Francis left in his message at the Fiftieth World Day of Peace on 1 January 2017 has been treasured and taken into heart.

Under rejection of international pressure theme, Daw Aung San Suu Kyi said:
"There has been a lot of criticism against our country. We need to understand international opinion. However, just as no one can fully understand our country's situation the way we do, no one can desire peace and development for our country than us. That is why we need to tackle these problems based on the strength of our unity" (Suu Kyi, Speeches 2017). This passage spoken after the world have seen the traumatised Rohingya as they walked towards to border between Myanmar and Bangladesh, in hordes, leaving the dead and bringing with them the stories of survival and pain.

In her report to the People speech, this passage has made her detached to the Rohingya's realities, calculating and cruel. It should take her continued denial of the crimes against the Rohingya to have existed, crimes such as rape, arson, ethnic cleansing, and genocide.

2nd Hypothesis - Form and Type of connexion;

For this hypothesis, Foucault talked about his attempts at studying descriptions as a form and type of connection in the study of nineteenth-century medical science. He rested in his analysis that medicine organised in a series of reports.

He said.

"I had to abandon this hypothesis at the outset and recognise that clinical discourse was just as much a group of hypothesis about life and death, of ethical choices, of therapeutic decisions, of institutional regulations, of teaching models, as a group of descriptions. These descriptions could not, in any case, abstracted from the hypotheses, and that the descriptive statement was only one of the formulations present in medical discourse" (Foucault, 1972).

Following his stand on descriptive statements and culling out from series of form and type of comments, we have chosen the form of ethical choices in analysing the discourse presented to the public by Daw Aung San Suu Kyi. We elevate the 
analysis by asking more questions, for now, and future research endeavours in this area.

It is because the person asking the questions is merely exercising the right that has given him; to remain unconvinced, to perceive a contradiction, to require more information, to emphasise different postulates, to point out faulty reasoning, and so on (Foucault, 1997). It was Foucault reply when interviewed by Paul Rabinow. He answered to the raised questions, "as for the person answering the questions. He too exercises a right that does not go beyond the discussion itself; by the logic of his discourse, he tied tow to the hat, said earlier, and by the acceptance of dialogue he tied to the questioning of the others" (Foucalt, 1997).

In sample 1, Daw Aung San Suu Kyi said "This does not mean that we are not ready to go on with our task of overcoming these challenges. Because I believe in the community of nations, I prepared to share with all our friends who wish us well and who understand our problems and sympathise with us, what we have been doing to achieve the democratic transition, peace and stability, and development."

In this description, she has an ethical choice of inclusively including the Rohingya and her party. The NLD plotted to spur the country towards full democratic transition, but she did not. Why did she leave the Rohingya in her narratives of democratic change towards peace, stability and development in Myanmar?

Why did she not bat for the amendment of the 1982 citizenship law that stripped the Rohingya birthright in Myanmar? It is very much part of the amendment the world wanted to see in Myanmar, not its questionable 2008 Constitution.

Why did she not recognise the Rohingya by their name and historicity? Because doing so will augur meaningful national reconciliation and peace as well as unity in the country.

In sample 2, Daw Aung San Suu Kyi has said: "The people of Myanmar have long been deprived of their inherent right to live in peace and security, to fundamental freedom and development, in the context of our 2030 goals, sustainable development."

Are the Rohingya not part of the people of Myanmar? Are they deprived of their right to a name and a nationality after 1982 citizenship law? Is it not their inherent right to live in peace and security too?

Why did she not include the Rohingya to appeal to the United Nations about her people deprived of fundamental freedom and development?

In sample 3, Daw Aung San Suu Kyi has said, in front of Pope Francis: "This is also a programme and a challenge for political and religious leaders, the heads of international institutions and business and media executives: to apply the Beatitudes in the exercise of their respective responsibilities."

It was in the same address that she defined what beatitudes mean.

To continue with her address, she said to the Pope: "Jesus himself offers a "manual" for this strategy of peacemaking in the Sermon on the Mount. The eight Beatitudes (cf Mt. 5:3-10) provide a portrait of the person we could describe as blessed, good and authentic. Blessed are the meek, Jesus tells us, the merciful and the peacemakers, those who are pure in heart, and those who hunger and thirst for justice."

Did she, in her address, intently leave the Rohingya and the atrocities they faced as a narrative devoid of meaning in the passage she mentioned to the Pope? Who are, in Myanmar, more in hunger and in thirst for justice? Is it not the Rohingya above anybody else?

Who needs peacekeeping in Myanmar? Is it not the Rohingya communities, after a crackdown and clearance opera- 
tions done by the Tatmadaw?

Who needs to exercise beatitudes the most? Is she not, as the leader of the Union of the Republic of Myanmar?

In sample 4, Daw Aung San Suu Kyi has said: "When I speak of democratic transition, I mean a democratic way towards a democratic goal, following a path laid down under the wishes of the people and maintained with their consent and cooperation".

Is it the desire of the majority to deprive the Rohingya their birthright? Was it their qualified wish to deny the Rohingya of their freedom and democratic way of life?

Is it not despotic to deprive the Rohingya these fundamental freedoms and right?

In sample 5, Daw Aung San Suu Kyi said: "the second and third on the list of tasks for the DACU are identifying priorities for development assistance, and the organisation of a new set of refreshed sector and thematic coordination groups."

She heads the Development Assistance Coordination Unit of the government.

Why has there been no tangible development assistance extended to the Rohingya communities in the northern Rakhine State? ment?

Why were they left out of develop-

In sample 6, Daw Aung San Suu Kyi said: "As we negotiate to reach common agreements on issues where our views differ, we must recognise that courtesy is not weakness, negotiation not a concession. Honesty, trust, awareness, and wisdom are necessary for negotiations to succeed."

Why does her government did not negotiate to end the atrocities against the Rohingya? Why is the civilian government not openly and truthfully asking the Tatmadaw to stop the atrocities and encourage accountability to be imposed?

Why did she remain silent than en- gaging in the realities of the Rohingya genocide?

In sample 7, she said that "ASEAN is now entering a wider area of regional integration as new and diverse challenges to sustainable development emerge: poverty, rising inequalities within and among the Member States, terrorism based on religious ideology, natural resource depletion. We must meet these challenges together, developing further our capacity for the united endeavour."

In this, why did she not address the high poverty levels in the northern Rakhine State? Why did her government not negotiate with the Rohingya to help them, not drive them away, from their homes?

Why did her government not embrace the Rohingya as an ethnic group in Myanmar to discourage the recruitment of ISIS in the poverty-stricken, neglected northern Rakhine State?

In sample 8, she said: "We are now negotiating with the Bangladesh Government to accept those who are now in Bangladesh."

Did she mean that the Rohingya in Cox's Bazar will not be able to return to their homes in the northern Rakhine State?

Did she just officially give away the Rohingya over to Bangladesh?

3rd Hypothesis - Not possible to establish groups of statements, by determining the system of permanent and coherent concepts involve;

In this, we seek to analyse her speeches in the interplay of their appearances and dispersion (Maniglier, 2013).

The discontinuity in all these eight speeches manifested on her selected occasion and audience. As observed, she skipped directly mentioning Rohingya and the genocide.

4th hypothesis - describes their interconnection and account for the unitary forms under which they presented: the identity and persistence of themes. 
In all her speeches, the forms remain to be strictly formal and uptight. Her revolving themes focus on peace and development and promoting Myanmar, which is understandable in State Counsellor's title. Still, she could not rally strong response against the military officials on how the Rohingya treated after 25 August 2017.

\section{Myanmar's Rule of Law}

Like any civilised nations on earth, Myanmar is a rules-based society, whatever its design or mechanism is - in civilian or military contexts. A study of the rule of law in Myanmar brings us back to Burma's history at the height of Aung San Suu Kyi's incarceration, then a prominent opposition leader.

The government of Myanmar has responded to worldwide dismay over the May 2009 criminal trial of democracy icon Daw Aung San Suu Kyi for allegedly violating the terms of her house arrest by characterising it as a simple and unavoidable matter of law. State-run media outlets have refuted arguments that the charges are baseless, erroneous and politically motivated. The Ministry of Foreign Affairs responded to criticism from the United Nations Security Council by saying that the case would "not have any political impact" and that it was being "considered and carried out as the task [sic] relating to the rule of law(Cheesman, 2009).

In this, Aung San Suu Kyi criminally indicted using the "rule of law" which is the same "rule of law" her government is borrowing as narratives against international pressures due to the Rohingya genocide.

Aung San Suu Kyi and the 'rule of law' has a symbiotic relationship, at her time of house arrest and now, as the State Counsellor of the Union. mean?

But what does the "rule of law"

Stephen Bloom wrote an opinion at the Irrawaddy. He illustrated that "the an- swer is important, because if Suu Kyi cannot articulate, communicate and get general agreement on what the "rule of law" means to the Burmese people. It threatens to become just a political slogan rather than a tangible goal towards which objective progress measured."

Efforts to strengthen social, economic and civil rights within the country further require policies and actions that educate people about their rights and furnish practical assistance to anyone whose rights have breached. It should accompany the revision or repeal of criminal statutes and decrees in the past validated repressive activity by the State, and a review of prison conditions and detentions to complement the amnesty process begun by President Thein Sein in May 2011. Steps must also be taken to broaden the country's narrow definitions of citizenship, which currently operate to deny at least 800,000 members of the Rohingya community and an unknown number of other people equal protection under statutory law and the 2008 Constitution (IBA 2012).

Going back to its origins, most laws in Myanmar today are importations from Great Britain and India as they were a colony for so many years.

On 1 January 1886, Myanmar became one of the provinces of British India. The statutory laws, which designed in the English common law model for use in India, were extended to Myanmar (then known as Burma). These statutory laws included the Contract Act, the Negotiable Instruments Act, the Sale of Goods Act, the Companies Act, the Arbitration Act, and the Civil and Criminal Procedure Codes. The Indian Penal Code, drafted and adopted in 1860, was also imported from India. By the early 1920s, when judicial administration had become well organised in the country, India's wholesale adoption of codes on British common law principles just completed. However, Myanmar has enacted numerous laws amending pre- 
independence laws, such as the Code of Civil Procedure (Amendment) Act in 1956, the Criminal Law Amending Law in 1963, the Code of Criminal Procedure Amending Law in 1973, the Law Amending the Myanmar Companies Act in 1989 and 1991, the law Amending the Civil Procedure Code in 2000 and 2008 (Justice Base, 2016).

In the study of the 'rule of law' in Myanmar, one has to go back in 2012 when the Constitutional Tribunal's nine judges 'voluntarily' resigned after impeachment proceedings against them prospered. While it hailed a triumph of parliamentary democracy, it has also impinged the Constitutional Tribunal's judicial independence.

The resignation of the members of the Constitutional Tribunal on 6 September 2012 went back to a decision issued by the Tribunal on 28 March 2012 in the case President of the Union v. Pyidaungsu Hluttaw, et al., which was only the fourth decision since the establishment of the Tribunal in February 2011. On 2 February 2012, the Union General of the Union submitted Submission No. 1/2012 to the Constitutional Tribunal on behalf of the President. They asked the Tribunal to resolve whether the committees, commissions and bodies formed by the Pyidaungsu Hluttaw, the Pyithu Hluttaw, and the Amyotha Hluttaw defined as Union level organisations. The Tribunal decided that the bodies created by each Hluttaw were not Union level organisations (Crouch, 2018).

Fast forward to 2018; the international community's shocked at violations of international law in Myanmar. Evidenced by the exodus of hundreds of thousands of Rohingya into Bangladesh and the plight of thousands more displaced people in the Shan and Kachin States overlooks a crucial national failing in prevention: Myanmar's legal system is unable to prevent human rights abuses or hold violators accountable. The result is a culture of impunity in which the State, rule by law.

Without the rule of law and human rights, upheld by an independent national legal system capable of balancing the executive and military power, there can be no safe return for displaced people. Recent government promises to assist returnees to access justice are therefore hollow (Crouch, 2018).

It is the reality that even Aung San Suu Kyi has to rally her people to institutionalised. Daw Aung San Suu Kyi said for the justice system to be strong, courts must be firm, particularly when tackling graft, as corrupt elements tend to take advantage of law for personal gain. At the same time, unbiased legal services remain a challenge in this country (Lin 2018). "If you keep beautiful laws confined to the books and do not apply them in a way that would benefit the public, then we can't say there is the rule of law," said the State Counsellor (Lin, 2018).

Problematising Daw Aung San Suu Kyi and the Rule of Law

To better understand issues surrounding the response of Myanmar of the accusations of genocide against the Rohingya, we will dwell on problematising her as the defector leader of the government and the principle of the rule of law in Myanmar.

First, the rule of law is perhaps the most powerful and often repeated political ideal in contemporary global discourse. Everyone, it seems, is for the rule of law. The rule of law is a major source of legitimation for governments in the modern world. A government that abides by the rule of law seen as good and worthy of respect. In recent decades, billions of dollars have been spent by the World Bank and other development agencies on developing the rule of law worldwide-with limited success (Tamanaha, 2012).

Quite a direct descendant, the rule of law in Myanmar as well as the majority of 
the world's nations, emanated from the Magna Carta of 1215, signed by England's King John, specifically under article 39, viz:

"No freemen should be taken, imprisoned, diseased, exiled or in any way destroyed, nor will we go upon him nor send upon him, except by the lawful judgment of his peers or by the law of the land."

Aptly stated, the rule of law is enshrined to govern the governed, set limits to what is under the aegis of a rules-based society and what is not.

The rule of law is difficult to maintain in any nation if the citizens do not follow the rule of law adopted.

The American Bar Association suggested that a 'rule of law' cannot ever be entirely separate from the people who make up our government and our society. The rule of law is ideal that we strive to achieve, but sometimes fail to live up.

In Myanmar, is the rule of law followed by its citizens, from ordinary folks from all walks of life to the military generals, who for many decades ruled Myanmar and its citizens under a military dictatorship?

According to the 2011 Rule of Law Handbook of the United States Army, the rule of law (ROL) used the description of Dr Richard Fallon in which it cited in toto (Cole, 2011):

"First, the ROL should protect against anarchy and the Hobbesian war of all against all. Second, the ROL should allow people to plan their affairs with reasonable confidence to know in advance the legal consequences of various actions. Third, the ROL should guarantee against at least some types of official arbitrariness.

Demands for the rule of law in response to violence in Myanmar's West correspond with this usage. Whereas in established democracies, the rule of law as equality complements law as security, the two are not necessarily compatible in a democratising state. The rule of law associated with substantive legal equality and contributes to Myanmar's democratisation. When associated with public and state security, it potentially undermines that democratisation (Cheesman, 2009).

As for Daw Aung San Suu Kyi, her narratives today linked to her past, in her childhood years surrounded by military generals loyal to his late father, Aung San, the Burmese military's prominent father.

She was born in 1945 in Rangoon, Burma. Aung San Suu Kyi spent her early years in Burma. She was just two years old when, on 19 July 1947, armed men burst in on a meeting convened to oversee Burma's transition to independence and killed her father and eight others. She grows up in the shadow of her legend father, largely shielded from the postindependence years' turmoil. At the Methodist English High School, in Rangoon, she took classes in morality and geography. Sao Haymar Thaike, a childhood friend and the daughter of Burma's first postindependence President, said that Suu Kyi was a serious, bookish girl, raised by a "powerful, kindhearted" mother, Khin Kyi. In 1960, Khin Kyi was appointed Ambassador to India and took her daughter with her. Two years later, Burma's coupinstalled a socialist military regime (Beech, 2017). She later joined her mother, who appointed as Burmese ambassador (representative) to India in 1960. She was partly educated in a secondary school in India and then attended St. Hugh's College, Oxford University, in England. While there, she studied politics, economics (the production, distribution, and use of goods and services), and philosophy (the study of ideas) and received her bachelor's and master's degrees. From her father, she developed a sense of duty to her country, and from her mother, who never spoke of hatred for her husband's killers, she learned forgiveness. She also became influenced by Indian leader Mohandas Gan- 
dhi (1869-1948), who was a believer in nonviolent civil disobedience.

Fast forward to 2007, the United States Institute of Peace paper on "Building Democracy in Burma" made the case that the country "falls more into the pattern of post-colonial Africa than it does Asia". Nearly a century of British rule left the foundations for democracy but Myanmar "like many countries in Africa, wasn't able to translate these into an enduring foundation for sustainable democratic governance" (Grant, 2018). It is along with Aung San Suu Kyi and her vision of the rule of law under democratic reforms and its ongoing transition.

A democracy icon who fell from grace, international leaders, outraged hundreds of thousands of Rohingya Muslims from Myanmar into neighbouring Bangladesh due to an army crackdown. They have accused her of doing nothing to stop rape, murder and possible genocide by refusing to condemn the powerful military or acknowledge accounts of atrocities (BBC, 2018).

\section{CONCLUSION}

On the part of Daw Aung San Suu Kyi, the study problematized her actions and silence over the Rohingya genocide and found out that her late father remains to be her greatest influencer owing to his great contribution as the father of modern Burmese military; And because of this special bond of her family with the military over the years, she sustained this bonds even during her house arrest. Another aspect that can be attributed to her silence on this issue was her drive and motivation, also focus, on her electoral promise in 2015 on Myanmar's democratic transition and because of this focus, it resulted to her democratic discourse by also obscuring the issue of the Rohingya and consider these as isolated events out to derail her efforts. Her context of the rule of law is only political dynamics and careful not to antagonize the military es- tablishment because perhaps out of fear that the military will take back her freedom and revert back to junta rule after 2015 and it is noteworthy that in all her speeches, she only uttered 10 times the words 'rule of law' against 14,910 words she uttered in all her separate eight speeches which indicates a token reference as the events unfold against the Rohingya. In Myanmar, the rule of law remains to be political narratives to appease the international community's outcry and demands for accountability because no high ranking military generals were held to account inside the country through its courts and this is being continually included in the ongoing legal reforms in the country after 2015 and sadly, this was also commonly-used to infer legality to justify the clearance operations against the Rohingya community in 2017.

\section{ACKNOWLEDGEMENT}

I would like to thank my colleagues at the Graduate School on Southeast Asian Studies, Centro Escolar University, Philippines for their support in the research process, focus group discussions and article writing.

\section{REFERENCES}

A/C.3/72/L.48. (2017, October 31). Retrieved September 29, 2018 , from UN Security Council: https:// www.securitycouncilreport.org/atf/ cf/\%7B65BFCF9B-6D27-4E9C8CD3-CF6E4FF96FF9\%7D/ a_c_3_72_1_48.pdf

Aguirre, D. (2018, June 4). Rule by Law and Impunity Undermine Prevention of and Accountability for Human Rights Violations in Myanmar. Retrieved October 3, 2018 , from Tea Circle Oxford : https:// teacircleoxford.com/2018/06/04/ rule-by-law-and-impunityundermine-prevention-of-andaccountability-for-human-rights- 
Available Online at https://journal.unismuh.ac.id/index.php/otoritas

Otoritas : Jurnal Ilmu Pemerintahan, 10 (2), October 2020, 195

violations-in-myanmar/

Baynes, C. (2018, August 30). Aung San Suu Kyi 'should have resigned' over Rohingya Muslim genocide, says UN human rights chief. Retrieved September 29, 2018, from The Independent : $\quad$ https:// www.independent.co.uk/news/ world/asia/aung-san-suu-kyirohingya-muslim-genocide-unhuman-rights-chief-zeid-raad-alhussein-a8513946.html

BBC. (2018, September 13). Aung San Suu Kyi: The democracy icon who fell from grace. Retrieved October 4, 2018 , from The BBC: https:// www.bbc.com/news/world-asiapacific- 11685977

BBC. (2018, August 29 ). Myanmar rejects UN accusation of 'genocide' against Rohingya. Retrieved September 29, 2018 , from BBC: https:// www.bbc.com/news/world-asia45338986

Beech, H. (2018, July 19 ). Myanmar's Military Planned Rohingya Genocide, Rights Group Says. Retrieved September 29, 2018 , from New York Times : https:// www.nytimes.com/2018/07/19/ world/asia/myanmar-rohingyagenocide.html

Beech, H. (2017, October 2). What Happened to Myanmar's Human-Rights Icon? Retrieved October 4, 2018 , from The New Yorker : https:// www.newyorker.com/ magazine/2017/10/02/whathappened-to-myanmars-humanrights-icon

Bloom, S. (2012, February 1). The 'Rule of Law' in Burma. Retrieved October 3, 2018 , from The Irrawaddy: http:// www2.irrawaddy.com/

opinion_story.php?art_id=22960

Cheesman, N. (2010). Thin Rule of Law or Un-Rule of Law in Myanmar? Pacific Affairs: Volume 82, No. 4, 597-613.

Cheesman, N. (2014). What Does the Rule of Law Have to do with Democratization (in Myanmar)? Southeast Asia Research https://doi.org/10.5367\% 2Fsear.2014.0203, 213-232.

Cole, M. (2011). The Rule of Law Handbook, A Practitioner's Guide for Judge Advocate. Charlottesville : Center for Law and Military Operations.

Dreyfus, R., \& Rabinow, P. (1983). Michel Foucault: Beyond Structuralism and Hermenutics . Chicago : University of Chicago Press.

Ellis-Petersen, H. (2018, August 27). Facebook removes accounts associated with Myanmar military. Retrieved September 29, 2018, from The Guardian : $\quad$ https:// www.theguardian.com/ technology/2018/aug/27/facebook -removes-accounts-myanmarmilitary-un-report-genociderohingya

Ellis-Petersen, H., \& Hogan, L. (2018, August 28). Aung San Suu Kyi stays silent on UN report on Rohingya genocide. Retrieved September 29, 2018, from The Guardian: https:// www.theguardian.com/ world/2018/aug/28/aung-san-suukyis-response-to-un-report-onrohingya-genocide-silence

England, K. (1994). Getting personal: Reflexivity, positionality, and feminist research. The Professional Geographer 46 (1) , 80-89. 
Available Online at https://journal.unismuh.ac.id/index.php/otoritas

Otoritas : Jurnal Ilmu Pemerintahan, 10 (2), October 2020, 196

Foucault, M. (1989). Order of Things, An Archaeology of the Human Sciences. New York: Routledge .

Foucault, M. (1997). Polemics, Politics and Problematization. In P. Rabinow, Michel Foucalt: Ethics Subjectivity and Truth (pp. 111-119). New York : The New York Press.

Foucault, M. (1972). The Archaeology of Knowledge and the Discourse on Language. New York: Tavistock Publications Limited.

Foucault, M. (1981). The Order of Discourse . In R. Young, Untying the Text: A Post-Structuralist Reader (pp. 48-78). Boston: Routledge and Kegan Paul.

Grant, S. (2018, March 20 ). Myanmar leader Aung San Suu Kyi can't be the messiah we want her to be. Retrieved October 4, 2018 , from ABC News: http://www.abc.net.au/news/201803-20/myanmar-leader-aung-sansuu-kyi-victim-to-westernexpectations/9566300

IBA. (2012). The Rule of Law in Myanmar: Challenges and Prospects . London : International Bar Association .

Keane, F. (2018, September 08). The Rohingya crisis: Why won't Aung San Suu Kyi act? Retrieved September 29, 2018, from BBC: https:// www.bbc.com/news/world-asia41187517

Kham, N. Y. (2014). An Introduction to the Law and Judicial System of Myanmar. Singapore : National University of Singapore .

Lin, N. Z. (2018, March 9). Rule of law and judiciary reform a priority: government. Retrieved October 3, 2018 , from The Myanmar Times : https:// www.mmtimes.com/news/rule-law -and-judiciary-reform-prioritygovernment.html

Luke, A. (1999). Critical Discourse Analysis . In J. P. Keeves, \& G. Lakomski, Issues in Educational Research . Oxford : Pergamon Press.

Lupton, D. (1992). Discourse analysis: A new methodology for understanding the ideologies of health and Illness . Australian Journal of Public Health $16,145-150$.

Mahtani, S. (2018, August 27). U.N. report calls for Myanmar generals to be prosecuted for genocide, war crimes . Retrieved September 24, 2018 , from The Washington Post : https:// www.washingtonpost.com/world/ un-report-calls-for-myanmargenerals-to-be-investigatedprosecuted-for-genocide-and-warcrimes/2018/08/27/fbf280a6-a9b5 $-11 \mathrm{e} 8-8 \mathrm{f} 4 \mathrm{~b}-$ aee063e14538_story.html? noredirect=on\&utm_term=.f36a94c37916

Mahtani, S. (2018, August 18). U.S. sanctions Myanmar military commanders and units for their role in 'ethnic cleansing'. Retrieved September 29, 2018 , from The Washington Post : https://www.washingtonpost.com/ world/asia_pacific/us-sanctionsmyanmar-military-commandersand-units-for-their-role-inethniccleansing/2018/08/17/71690820a22a-11e8-b5621db4209bd992_story.html? utm_term=.b23417e85427

Marti, G. (2015). The Role of the Constitutional Tribunal in Myanmar's Reform Process. Asian Journal of Comparative Law, 10 doi:10.1017/ 
asjcl.2015.2 , 153-184.

McLaughlin, T. (2018, August 27). Facebook blocks accounts of Myanmar's top general, other military leaders. Retrieved September 29, 2018 , from The Washington Post : https:// www.washingtonpost.com/world/ asia_pacific/facebook-blocksaccounts-of-myanmars-top-generalother-militaryleaders/2018/08/27/da1ff440-a9f6 $-11 \mathrm{e} 8-9 \mathrm{a} 7 \mathrm{~d}-$ cd30504ff902_story.html? utm_term=.cd2062f5190f

Nebehay, S., \& Lewis, S. (2018, March 7). 'Acts of genocide' suspected against Rohingya in Myanmar: U.N. Retrieved September 29, 2018 , from Reuters : https://www.reuters.com/ article/us-myanmar-rohingyarights/acts-of-genocide-suspectedagainst-rohingya-in-myanmar-u-nidUSKCN1GJ163

NYT. (2018, September 20). Canada Declares Myanmar Treatment of Rohingya to Be Genocide. Retrieved September 29, 2018 , from The New York Times : https:// www.nytimes.com/ aponline/2018/09/20/world/asia/ ap-cn-canada-myanmarrohingya.html

OHCHR. (2018, August 24). Retrieved September 24, 2018, from https:// www.ohchr.org/Documents/ HRBodies/HRCouncil/FFMMyanmar/A_HRC_39_64.pdf

Rahimi, F., \& Javad Riasati, M. (2011). Critical Discourse Analysis: Scrutinizing Ideologically-Driven Discourses. International Journal of $\mathrm{Hu}$ manities and Social Science Vol. 1 Number 18, 107-112.
Slodkowski, A. (2018, August 27). Facebook bans Myanmar army chief, others in unprecedented move. Retrieved September 29, 2018 , from Reuters: https://www.reuters.com/ article/us-myanmar-facebook/ facebook-bans-myanmar-army-chief -others-in-unprecedented-moveidUSKCN1LCOR7

Smith, N. (2018, August 30). Aung San Suu Kyi should have resigned over Rohingya crisis, says UN human rights chief. Retrieved September 29, 2018 , from The Telegraph : https:// www.telegraph.co.uk/ news/2018/08/30/aung-san-suukyi-should-have-resigned-rohingyacrisis-says-un/

Suu Kyi, A. S. (2017, August 14). Speech . Retrieved September 25, 2018 , from The State Counsellor : http:// www.statecounsellor.gov.mm/en/ node/1111

Suu Kyi, A. S. (2017, May 25). Speech. Retrieved September 25, 2018, from State Counsellor: http:// www.statecounsellor.gov.mm/en/ node/883

Suu Kyi, A. S. (2016, September 21). Speeches . Retrieved September 26, 2018, from Voltaire : http:// www.voltairenet.org/ article198120.html

Suu Kyi, A. S. (2017, November 29). Speeches . Retrieved September 25, 2018, from The State Counsellor : http:// www.statecounsellor.gov.mm/en/ node/1405

Suu Kyi, A. S. (2017, October 12). Speeches . Retrieved September 25, 2018 , from The State Counsellor : http:// www.statecounsellor.gov.mm/en/ 
Available Online at https://journal.unismuh.ac.id/index.php/otoritas

Otoritas : Jurnal Ilmu Pemerintahan, 10 (2), October 2020, 198

node/1072

Suu Kyi, A. S. (2018, February 27). Speeches . Retrieved September 25, 2018 , from The State Counsellor : http://

www.statecounsellor.gov.mm/en/ node/1751

Suu Kyi, A. S. (2018, August 23). Speeches . Retrieved September 25, 2018 , from The State Counsellor : http:// www.statecounsellor.gov.mm/en/ node/2111

Suu Kyi, A. S. (2017, September 17). Speeches. Retrieved September 25, 2018, from Voltaire : http:// www.voltairenet.org/ article198013.html

Tamanaha, B. Z. (2012). The History and Elements of the Rule of Law . Singapore Journal of Legal Studies , 232247. van Dijk, T. A. (1993). Principles of Critical Discourse Analysis . Discourse and Society , 249-283.

Washington Post . (2018 , August 29). Retrieved September 24, 2018 , from https://www.washingtonpost.com/ opinions/global-opinions/what-ishappening-in-myanmar-is-genocide -call-it-by-itsname/2018/08/29/611a1090-aafe11e8-a8d70f63ab8b1370_story.html? utm_term $=.7 \mathrm{e} 4334 \mathrm{c} 791 \mathrm{fc}$

Wilkinson, B. (2018, March 12). UN official convinced of Myanmar Rohingya 'genocide'. Retrieved September 29, 2018 , from CNN: https:// edition.cnn.com/2018/03/12/ asia/myanmar-rohingya-unviolence-genocide-intl/index.html 